This is the author's final, peer-reviewed manuscript as accepted for publication. The publisher-formatted version may be available through the publisher's web site or your institution's library.

\title{
Pyrethroid resistance and its inheritance in a field population of Hippodamia convergens (Guérin-Méneville) (Coleoptera: Coccinellidae)
}

Agna Rita S. Rodrigues, John R. Ruberson, Jorge B. Torres, Herbert Álvaro A. Siqueira \& Jeffrey G. Scott

\section{How to cite this manuscript}

If you make reference to this version of the manuscript, use the following information:

Rodrigues, A. R. S., Ruberson, J. R., Torres, J. B., Siqueira, H. A. A., \& Scott, J. G. (2013). Pyrethroid resistance and its inheritance in a field population of Hippodamia convergens (Guérin-Méneville) (Coleoptera: Coccinellidae). Retrieved from http://krex.ksu.edu

\section{Published Version Information}

Citation: Rodrigues, A. R. S., Ruberson, J. R., Torres, J. B., Siqueira, H. A. A., \& Scott, J. G. (2013). Pyrethroid resistance and its inheritance in a field population of Hippodamia convergens (Guérin-Méneville) (Coleoptera: Coccinellidae). Pesticide Biochemistry and Physiology, 105(2), 135-143.

Copyright: (C) 2013 Elsevier Inc.

Digital Object Identifier (DOI): doi:10.1016/j.pestbp.2013.01.003

Publisher's Link: http://www.sciencedirect.com/science/article/pii/S0048357513000175

This item was retrieved from the K-State Research Exchange (K-REx), the institutional repository of Kansas State University. K-REx is available at http://krex.ksu.edu 


\section{Pyrethroid Resistance and Its Inheritance in a Field Population of}

\section{Hippodamia convergens (Guérin-Méneville) (Coleoptera: Coccinellidae)}

3

4 Agna Rita S. Rodrigues ${ }^{\mathrm{a}}$, John R. Ruberson ${ }^{\mathrm{b},{ }^{*},}$, Jorge B. Torres ${ }^{\mathrm{a}}$, Herbert Álvaro A. Siqueira ${ }^{\mathrm{a}}$

$5 \quad \&$ Jeffrey G. Scott ${ }^{\mathrm{c}}$

6

7

$8{ }^{\mathrm{a}}$ Departmento de Agronomia/Entomologia, Universidade Federal Rural de Pernambuco, Rua

9 Dom Manoel de Medeiros S/N, Dois Irmãos, Recife, PE 52171-900, Brazil. E-mail:

10 agnarodrigues@yahoo.com.br,jtorres@depa.ufrpe.br,siqueira@depa.ufrpe.br

$11{ }^{b}$ Department of Entomology, Kansas State University, 123 West Waters Hall, Manhattan, KS

12 66505,USA.E-mail: ruberson@k-state.edu

$13{ }^{c}$ Department of Entomology, Cornell University, 2128 Comstock Hall, Ithaca, NY 14853,

14 USA.E-mail:jgs5@cornell.edu

15

16

17 *Corresponding author:

18 John Russell Ruberson

19 Ph: 785-532-4712

20 Fax: 785-532-6232

21 


\section{Abstract}

23 The convergent lady beetle (CLB), Hippodamia convergens (Guérin-Méneville), a species

24 widely distributed and used in biological control, has exhibited high survival under field and

25 laboratory conditions when treated with field rates of the pyrethroid $\lambda$-cyhalothrin, a highly

26 unusual phenomenon for a natural enemy. This work investigated and characterized the

27 phenomenon of pyrethroid resistance in a population of this species collected in Georgia,

28 USA. The mechanism and level of resistance were evaluated by treating parental populations

29 with $\lambda$-cyhalothrin \pm piperonyl butoxide (PBO). The inheritance bioassay utilized parental

30 crosses and backcrosses between parental populations to obtain testable progenies. Adult

31 beetles from populations and progenies were topically treated with different doses of $\lambda$ -

32 cyhalothrin (technical grade) to calculate knockdown (KD) and lethal (LD) doses, and to

33 investigate the dominance based on a single dose and whether resistance is autosomal and

34 monogenic (null hypothesis). Genetic variation in the parental populations was examined by

35 applying a discriminating dose for resistant individuals $(0.5 \mathrm{~g} / \mathrm{L})$. The data indicate that

36 resistance is due to at least two factors: knockdown resistance and enzymatic detoxification of

37 the insecticide. The knockdown effect is recessive and linked to the $\mathrm{X}$-chromosome.

38 Variability in proportions of individuals within families dying following knockdown indicated

39 genetic variation in the resistant population. Further studies should be done to investigate the

40 role of sex linked inheritance of resistance in the species and interactions of the various

41 mechanisms involved in resistance.

42

43 KEY WORDS: Lady beetles; pyrethroid; resistance inheritance; piperonyl butoxide; $\lambda$ -

44 cyhalothrin 


\section{Introduction}

Effective integration of insecticides and natural enemies has been a goal of integrated pest management (IPM) since the concept was first fully articulated by Stern et al. [1], although at the time and in the subsequent decades this integration has seemed highly unlikely. Most organophosphate, carbamate, and pyrethroid insecticides have broad activity spectra, with little selectivity toward natural enemies [2]. Insecticides can affect natural enemies, manifesting as death or alterations in behavior and fitness, via direct intoxication from insecticide application, or indirectly through consumption of contaminated prey or through scarcity of prey or hosts $[3,4]$.

Overcoming this incompatibility is the most difficult aspect of integrating biological control agents and insecticides in IPM strategies. An ideal resolution is to replace all broad spectrum products with insecticides of greater selectivity $[5,6]$, but this is highly impractical at present. Some efforts have been made to utilize insecticide-resistant natural enemies in IPM, but such resistance in natural enemies is highly unusual relative to that observed in pests.

Intensive insecticide use has selected for resistance to multiple classes of insecticides in numerous arthropod species, the vast majority of which are herbivores. Since 1914, when the first instance of resistance was observed in the San Jose scale, Quadraspidiotus perniciosus (Comstock) (Hemiptera: Diaspididae), more than 500 pest species resistant to insecticides have been recorded [7]. Insecticide resistance in natural enemies has also been reported, but much less frequently than for pest species. The predatory mite Neoseiulus (=Amblyseius) fallacis (Garman) (Acari: Phytoseiidae) was found to be resistant to azinphosmethyl in the 1970s [8]. Subsequently, more cases were observed in predatory mites [9, 10]. Among insect natural enemies, field resistance has been reported for the parasitoid Anisopteromalus calandrae (Howard) (Hymenoptera: Pteromalidae) to malathion [11], and populations of the 
71 lacewing Chrysoperla carnea (Stephens) (Neuroptera: Chrysopidae) have exhibited resistance 72 to carbaryl [12] and organophosphates and pyrethroids [2, 13, 14]. Similarly, Suckling et al. 73 [9] found pyrethroid-resistant predatory mites in apple orchards in New Zealand.

74 Although Coccinellidae have been widely studied and used in biological control for

75 over a century, insecticide resistance has rarely been reported in this group of natural enemies.

76 Lady beetles commonly occur in many ecosystems and are valued for their contributions to

77 biological control of soft-bodied arthropod pests, such as aphids, whiteflies, scales, and mites

$78[6,15,16]$. Relative to other entomophages, lady beetles tend to be less susceptible to

79 insecticides than other aphidophagous natural enemies, such as lacewings, syrphids,

80 hemipterans, and hymenopteran parasitoids [17]. Studies of different species and populations

81 of lady beetles and insecticides reveal variation in lady beetle susceptibility to insecticides

$82[18,19,20,21,22,23,24]$, and this variation may be fodder for selection of insecticide

83 resistance in the field. Indeed, Coleomegilla maculata (De Geer) (Coleoptera: Coccinellidae)

84 populations in cotton fields were found to be resistant to DDT and several organophosphates

85 by Head et al. [25] and Graves et al. [26]. More recently, a population of another lady beetle

86 species, Eriopis connexa (Germar) (Coleoptera: Coccinellidae), collected from cabbage fields

87 in Brazil was found to be 20 -fold resistant to the pyrethroid $\lambda$-cyhalothrin relative to other

88 populations [24].

89 The convergent lady beetle (CLB) Hippodamia convergens (Guérin-Méneville) is a

90 cosmopolitan species important in numerous agroecosystems [27]. Being widely distributed,

91 populations of CLB are exposed to a wide variety of insecticides across time and space [19,

$9223,28,29,30]$. This fact may explain differential survival among lady beetle species of cotton

93 fields in Georgia, USA, when exposed to $\lambda$-cyhalothrin, a broad spectrum pyrethroid

94 insecticide frequently used in various crops $[23,28,30,31]$.

95 This study was conducted to investigate pyrethroid resistance (specifically, $\lambda$ - 
99

100

101

102

103

104

105

106

107

108

109

110

111

112

113

114

115

116

117

118

119

120

cyhalothrin) in CLB in Georgia and to determine if the metabolism involved is suppressed by the synergist piperonyl butoxide (PBO). Furthermore, inheritance of the resistance and number of factors involved in the resistance were also examined.

\section{Material and Methods}

This study was carried out at the Biological Control Laboratory of the Tifton Campus of the University of Georgia (Tifton, GA).

2.1. Chemicals. The insecticide used in the experiments was the pyrethroid $\lambda$-cyhalothrin (technical grade 99.5\%; Chem Service, West Chester, PA, USA) and the synergist piperonyl butoxide (PBO) at 80\% (Endura PB 80 EC-NF, 80\% PBO, Endura Fine Chemicals, Bologna, Italy).

2.2. Sources of $\boldsymbol{H}$. convergens (CLB) populations. Two populations of $H$. convergens were established and maintained in the laboratory. One population (designated 'Hc-CA'), which originated from field collections in California (Central Valley near Fresno, CA), was purchased in April 2011 from ARBICO Organics (Oro Valley, AZ). The second population (designated 'Hc-GA') was established from beetles collected in crimson clover in Decatur County, Georgia, USA (coordinates 30 45' 45.34” N and 84 $28^{\prime} 49.75 ”$ W) in April 2011.

\subsection{CLB maintenance. Larvae and adults were reared using eggs of Ephestia kuehniella}

(Zeller) (Lepidoptera: Pyralidae), obtained from Beneficial Insectary Inc. (Redding, CA, USA). Beetles were held in environmentally controlled conditions of $25 \pm 1^{\circ} \mathrm{C}$, and a photoperiod of 14:10h (L:D) for all rearing and bioassays. The two populations were maintained separately. Adults were kept in cylindrical plastic containers $(30 \mathrm{~cm}$ long, wide and high) containing openings on the sides closed with nylon mesh. Later, individual pairs were held in 500-ml plastic containers with a mesh-covered opening in the lid to allow ventilation, and a piece of paper towel as an oviposition substrate. Eggs were transferred to transparent 
12130 -mL plastic cups. Eggs produced by at least 20 adult pairs were used to maintain the

122 colonies and to provide insects for bioassays. Newly eclosed larvae were held individually in

$12330-\mathrm{ml}$ plastic cups and provided ad libitum with eggs of E. kuehniella.

124 2.4. Dose-response curves. Adults of the $\mathrm{F}_{1}$ generation from both populations (Hc-CA and

125 Hc-GA) were treated with the insecticide $\lambda$-cyhalothrin to determine the lethal dose $\left(\mathrm{LD}_{50}\right)$.

126 Preliminary bioassays were carried out to define doses which resulted in mortality from 0 to

$127100 \%$. Insects were topically treated by applying a $0.5 \mu 1$ droplet of the appropriate solution to

128 the venter of the adult abdomen using a Hamilton syringe ( $25 \mu \mathrm{L}$-volume). Based on

129 preliminary tests six doses for each population $(0.001,0.002,0.004,0.006,0.008$, and $0.01 \mathrm{~g}$

130 a.i./L for Hc-CA; and 0.1, 0.3, 0.5, 0.7, 1.0, and $1.3 \mathrm{~g}$ a.i./L for Hc-GA) were selected for

131 calculating the dose-mortality curve and the $\mathrm{LD}_{50}$. At least 20 adults (8 to 10 days old) were

132 tested per dose.

133 Treated and control groups were kept in petri dishes (12 cm diameter, and $1.5 \mathrm{~cm}$ high)

134 lined with filter paper and provided with a $10 \%$ honey solution soaked in cotton batting inside

135 the petri dishes. Petri dishes with insects were stored in a climatic chamber at $25 \pm 1^{\circ} \mathrm{C}$ and

136 photoperiod 14:10h (L:D). Knockdown and mortality were assessed 2 and $24 \mathrm{~h}$ after

137 insecticide application, respectively. A beetle was considered to be knocked down or dead if it

138 was unable to turn upright and begin to walk after being placed on its dorsum at the respective

139 observation intervals.

140 2.5. Dose-response curves with the synergist PBO. The insecticide $\lambda$-cyhalothrin (99.5\%

141 technical grade) and the synergist PBO were applied in the bioassay diluted in acetone.

142 Previous tests of varying doses of PBO indicated that $10 \mathrm{~g}$ a.i. of $\mathrm{PBO} / \mathrm{L}(10 \mathrm{ppm})$ was the

143 maximum sublethal dose and could be used in the dilutions to be tested. Thus, the synergism

144 ratio using $\mathrm{PBO}$ was determined for Hc-GA and Hc-CA populations by treating the insects

145 with $\lambda$-cyhalothrin dosage including PBO at $10 \mathrm{~g}$ a.i./L. The tested dosages of $\lambda$-cyhalothrin 
146 alone began with a high dosage of $1 \mathrm{~g}$ a.i./L, which was then serially diluted by factors of 10

147 during the preliminary test to obtain the final dosages. The dosages of $\lambda$-cyhalothrin $+\mathrm{PBO}$

148 used were: $0.0002,0.0004,0.0006,0.0008,0.001$, and $0.003 \mathrm{~g}$ a.i./L for Hc-CA; and 0.005,

$1490.01,0.03,0.05,0.08,0.10$, and $0.5 \mathrm{~g}$ a.i./L for Hc-GA. The bioassay was conducted using $\lambda$ -

150 cyhalothrin + PBO, as well as control treatments using only PBO or acetone.

151 2.6. Dominance and role of sex linkage in resistance. The $F_{1}$ progeny was tested to evaluate 152 possible sex linkage related to the resistance. Females and males were kept individually in

153 transparent 30-ml plastic cups. Sexes were differentiated based on the shape of the distal

154 margin of the fourth visible abdominal sternite. The posterior margin of the fourth sternite has

155 a concave shape in males while in females it is a straight line. Reciprocal crosses between

156 virgin females $(n=30)$ and males $(n=30)$ from resistant (Hc-GA) and susceptible (Hc-CA)

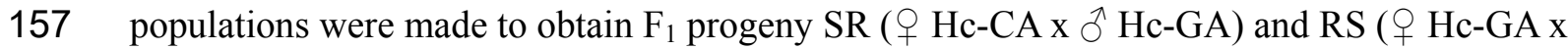

$158 \widehat{\jmath}$ Hc-CA). Free mating choice was allowed by pairing females and males of the two parental

159 populations in plastic containers ( $30 \mathrm{~cm}$ long, wide and high). Each $\mathrm{F}_{1}$ cross progeny (SR and

160 RS) was reared separately to obtain sufficient adults to calculate the $\mathrm{LD}_{50}$.

161 To test for sex linkage, males from both $\mathrm{F}_{1}$ reciprocal crosses $(n=30)(\mathrm{SR}$ and $\mathrm{RS})$ were

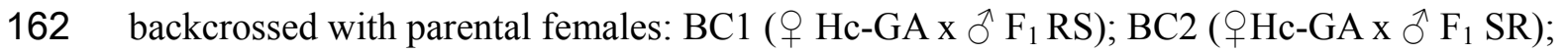

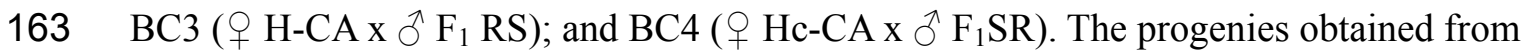

164 backcross pairings were reared separately to obtain sufficient adults for each backcross to

165 calculate the $\mathrm{LD}_{50}$ using 6 - $10 \lambda$-cyhalothrin doses.

166 2.7. Dominance of resistance in $H$. convergens to $\lambda$-cyhalothrin based on a single dose. In

167 this bioassay we used 8-d old adults of the population groups Hc-CA $(n=120)$, HC-GA $(n=$

168 120), $F_{1} R S(n=120)$ and $F_{1} S R(n=120)$. Five previously determined doses of $\lambda$-cyhalothrin

$169(0.001,0.01,0.1,0.5$, and $1.0 \mathrm{~g}$ of a.i./L) were administered to adults of the different

170 population groups as previously described. The control group was treated only with acetone 
$171(\mathrm{n}=10)$. The knockdown effect and mortality were assessed 2 and $24 \mathrm{~h}$ after insecticide

172 application, respectively.

173 2.8. Genetic variation within susceptible and resistant populations of $\boldsymbol{H}$. convergens. We

174 tested Hc-CA and Hc-GA for homozygosity of resistance traits in the respective populations.

175 Individual virgin females and males $(n=5)$ were paired for mating and egg production to

176 compose five separate families. Then virgin female and male offspring of Hc-CA, Hc-GA, $\mathrm{F}_{1}$

177 reciprocal crosses, $\mathrm{F}_{1} \mathrm{RS}$ and $\mathrm{SR}$, and the four backcrosses (BC1 to $\left.\mathrm{BC} 4\right)$ were tested with a

178 discriminating dose of $0.5 \mathrm{~g}$ a.i of $\lambda$-cyhalothrin/L for homozygous resistance $\left(\mathrm{X}^{\mathrm{R}} \mathrm{X}^{\mathrm{R}}\right.$ and

$179 \mathrm{X}^{\mathrm{R}} \mathrm{y}$ ) following the same procedures used in the previous tests. Each adult pair corresponded

180 to a population family or specified cross progeny. By examining offspring in individual

181 families we could compare observed results with what would be expected for a homozygous

182 population in detail, allowing us to discern individual deviations from homozygosity that

183 could otherwise confound interpretation of results $[32,33]$. As a component of this, the sex

184 determination system of $H$. convergens must be considered in evaluating a sex linkage model

185 for inheritance of insecticide resistance. The CLB has been characterized as $2 n=18$

186 autosomal and having homogametic females (XX) and heterogametic (Xy) males [34].

187 Therefore, males will be homozygous for traits acquired from the female on the $\mathrm{X}$

188 chromosome.

189 2.9. Data analysis. The number of individuals exhibiting knockdown, death or survival per

190 dose in the resistance inheritance and synergism tests were used to calculate the knockdown

191 dose (KD) and the lethal dose (LD) for each population or progeny with the computer

192 program Polo PC [35], based on Probit analysis [36]. Correction for natural mortality was

193 unnecessary since control survival in all cases was $100 \%$. A $\chi^{2}$ goodness-of-fit test was used

194 to test for parallelism and equality of the dose-mortality curves between populations. Data

195 from resistance inheritance bioassays were used to obtain the resistance ratio (RR) between 
196

197

198

199

200

201

202

203

204

205

206

207

208

209

210

211

212

213

214

215

216

21

21 219

220

resistant and susceptible populations based on the KD and LD calculated for each population, F1 progenies, and backcrosses. Likewise, the synergism ratio (SR) and the resistance ratio (RR) were calculated for treatments with $\lambda$-cyhalothrin only or when the synergist PBO was added. The RR and SR and their respective $95 \%$ confidence intervals (CI) were calculated and considered significant when the CI did not include the value 1.0, following the method of Robertson \& Preisler [37].

Autosomal or sex-linked inheritance of resistance in $H$. convergens to $\lambda$-cyhalothrin was tested using the $\mathrm{KD}$ and $\mathrm{LD}$ determined for $\mathrm{F}_{1}$ adults from reciprocal crosses between $\mathrm{Hc}$-GA and Hc-CA populations, $\mathrm{F}_{1} \mathrm{RS}$ and $\mathrm{F}_{1}$ SR progenies. The degree of dominance $(D)$ was estimated using the method of Stone [38], which is based on the KD or LD values. The standard error (SE) of the degree of dominance was calculated following the method of Lehmann [39], and interpreted after Preisler et al. [40]. The dominance (h) was estimated based on a single dose, following Hartl [41].

The minimum number of genes controlling resistance was investigated using the method of Lande [42] based on $\mathrm{KD}_{50}$ and $\mathrm{LD}_{50}$ responses. The minimum number of genes driving resistance was calculated separately for $\mathrm{F}_{1}$ progeny of $H$. convergens and the respective backcrosses.

To evaluate genetic variation of parental populations, observed knockdown and mortality were initially corrected for the number of males and females of $H$. convergens tested. Thus, the testable hypothesis for genetic homozygosity is that the proportion of observed knockdown or mortality would be equal to the proportion of expected knockdown or mortality based on the sex-linked inheritance for $H$. convergens, assuming the recessive inheritance of resistance found with the discriminatory dose $(0.5 \mathrm{~g}$ a.i. of $\lambda$-cyhalothrin/L). Thus, using the G-statistic goodness of fit test for heterogeneity [43], homogeneity was tested among families and the hypothesis of absence of genetic variation was tested within and 
221 among families. The goodness of fit test was carried out only on the results for $\mathrm{F}_{1} \mathrm{RS}$ and for

222 the backcross $\mathrm{BC} 2(+\mathrm{Hc}-\mathrm{GA} \mathrm{x} \stackrel{\widehat{\mathrm{F}}}{\mathrm{F}} \mathrm{SR})$. The test was not conducted for families of the

223 susceptible population (Hc-CA), the $\mathrm{F}_{1}$ SR progeny or their respective backcrosses (BC3 and

224 BC4) because the knockdown and mortality responses observed were as expected for all

225 families (1.00). Furthermore, for the resistant population (Hc-GA) and the backcross BC1 (ㅇ

226 Hc-GA $\left.x \curvearrowright F_{1} R S\right)$, the expected mortality is null (0.00) and, therefore, a $G$-statistic could not

227 be calculated.

228

229 3. Results

230 3.1. Dose-response curves. The knockdown results fit the Probit model $(\mathrm{P}>0.05)$. In contrast,

231 the dose-mortality curves differed in parallelism and equality $(\mathrm{P}<0.05)$; thus the $\mathrm{KD}_{50 \mathrm{~s}}$ and

$232 \mathrm{KD}_{90 \mathrm{~s}}$ were calculated (Table 1). Based on $\mathrm{KD}_{50}$ and $\mathrm{KD}_{90}$ from evaluations $2 \mathrm{~h}$ post-treatment

233 the Hc-GA population was over 286 and 461 -fold more resistant by knockdown effect to $\lambda$ -

234 cyhalothrin than Hc-CA adults (Table 1). The $\mathrm{LD}_{50}$ and $\mathrm{LD}_{90}$ of the Hc-CA population were,

235 respectively, 0.004 and $0.816 \mathrm{~g}$ a.i. of $\lambda$-cyhalothrin/L, compared to 0.015 and 4.595 ,

236 respectively, for the Hc-CA and Hc-GA populations. Based on these values, the Hc-GA

237 population was over $220\left(\mathrm{LD}_{50}\right)$ and 308.0 -fold $\left(\mathrm{LD}_{90}\right)$ more resistant to $\lambda$-cyhalothrin than

238 the Hc-CA population (Table 1).

239 3.2. Dose-mortality curves with the synergist PBO. Adults from both populations exhibited

240 similar patterns of response for knockdown and mortality when treated with $\lambda$-cyhalothrin

241 plus the synergist PBO, but differed when using $\lambda$-cyhalothrin alone (Table 2). The $\mathrm{KD}_{50}$ and

$242 \mathrm{LD}_{50}$, however, were lower than when only $\lambda$-cyhalothrin was applied. The $\mathrm{KD}_{50}$ and $\mathrm{LD}_{50}$

243 synergism ratios were 1.62 and 6.94 (KD); and 5.53 and 17.24 (LD) for Hc-CA and Hc-GA

244 populations, respectively. The resistance ratio (RR) of $\lambda$-cyhalothrin based on the $\mathrm{KD}_{50}$ or

$245 \mathrm{LD}_{50}$ was reduced approximately 3-4 fold to $\sim 70$ for Hc-GA relative to Hc-CA when PBO was 
246 added (Table 2). These results further demonstrate that the Hc-GA population is more resistant

247 to $\lambda$-cyhalothrin than the Hc-CA population. Furthermore, the $\mathrm{LD}_{90}$ calculated for the Hc-GA

248 population is 10.44 times greater than the highest field rate of $\lambda$-cyhalothrin recommended to

249 spray cotton $(0.44 \mathrm{~g}$ a.i./L).

250 3.3. Dominance and role of sex linkage in resistance. The RR for the $F_{1} R S$ beetles was

251 greater than that of the $\mathrm{F}_{1}$ SR beetles when calculated using the $\mathrm{KD}_{50}, \mathrm{KD}_{90}, \mathrm{LD}_{50}$, and $\mathrm{LD}_{90}$

252 values, suggesting that resistance is X-linked (Table 1). Further the degree of dominance

253 varied from -0.66 to -0.13 based on $\mathrm{KD}_{50}$, and from -0.48 to 0.27 based on $\mathrm{KD}_{90}$ (Table 1 ).

254 The resistance ratios of the $\mathrm{KD}_{50}$ for $\mathrm{BC} 1$ and $\mathrm{BC} 2$, both of which were offspring of $\mathrm{Hc}-\mathrm{GA}$

255 mothers, were 211.33 and 70.47 -fold, respectively, whereas the $\mathrm{KD}_{50}$ resistance ratios for

$256 \mathrm{BC} 3$ and $\mathrm{BC} 4$, which were offspring of Hc-CA mothers, were 2.81 and 2.91, respectively.

257 These results are consistent with X-linked resistance. Despite the low ratios for BC3 and BC4

258 they were significantly different from the parental Hc-CA population according to the method 259 of Robertson and Preisler [37] (Table 1).

260 The mortality data for the progenies and backcrosses fit a Probit model $(\mathrm{P}>0.05)$, except

261 for the mortality of the $\mathrm{F}_{1}$ RS progeny $(\mathrm{P}<0.05)$. There were significant differences between

262 the $\mathrm{F}_{1}$ progenies (SR and $\mathrm{RS}$ ) in both the $\mathrm{LD}_{50}$ and $\mathrm{LD}_{90}\left[\mathrm{RR}_{50(\mathrm{IC} 95 \%)}: 7.44(4.48-12.35)\right.$ and

$\left.263 \mathrm{TR}_{90(\mathrm{IC} 95 \%)} 24.11(8.56-67.87)\right]$, which, taken with the backcross results, strongly suggests a

264 maternal effect or X-linked. The degree of dominance varied from -0.28 to 0.47 for the $\mathrm{LD}_{50}$,

265 from -0.34 to 0.78 for the $\mathrm{LD}_{90}$ (Table 1 ).

266 3.4. Dominance of resistance in $H$. convergens to $\lambda$-cyhalothrin based on a single dose.

267 The results indicate recessive dominance in the $\mathrm{F}_{1}$ progenies tests and variability in the

268 resistance based on single dose results. The resistance was found to be functionally dominant

$269(h=1.0)$ for the Hc-GA population at the lowest tested dose $(0.001)$ for both reciprocal

270 crosses (RS and SR) (Table 3). For $\mathrm{F}_{1} \mathrm{SR}$, however, resistance was functionally recessive $(h=$ 
$2710.0)$ at doses of 0.1 and $1.0 \mathrm{~g}$ a.i. of $\lambda$-cyhalothrin/L at 2 and $24 \mathrm{~h}$ evaluations, respectively;

272 while for $\mathrm{F}_{1} \mathrm{RS}$ it was recessive only at the highest tested dose at knockdown $2 \mathrm{~h}$ post-

273 treatment (Table 3 ). Based on mortality evaluated $24 \mathrm{~h}$ post-treatment the effective dominance

274 ranged from 0.32 to 0.5 for doses greater than $0.1 \mathrm{~g}$ a.i. of $\lambda$-cyhalothrin/L for $\mathrm{F}_{1} \mathrm{RS}$ (Table

$2753)$.

276 3.5. Minimum number of loci. The number of loci coordinating resistance in $H$. convergens

277 to $\lambda$-cyhalothrin was estimated at -4.39 and 0.74 genes for the $F_{1} R S$ and $F_{1}$ SR progenies, and

278 for their respective backcrosses. On the other hand, when considering the mortality data, the

279 number of genes coordinating resistance is estimated at -1.23 and 3.73 for the $\mathrm{F}_{1}$ progenies SR

280 and RS, and their backcrosses, respectively.

281 3.6. Genetic variation within susceptible and resistant populations of $\boldsymbol{H}$. convergens. The

282 paired females and males from Hc-GA and the $\mathrm{F}_{1} \mathrm{RS}$ progeny resulted in four pairs that

283 produced viable offspring (families), out of the five pairs set up. Thus, only four families were

284 utilized for the BC1 and BC3 backcrosses. The knockdown and mortality results indicated

285 that Hc-GA male parents, used to form the $q$ Hc-GA $x \stackrel{\jmath}{\jmath}$ Hc-GA families, were not

286 susceptible to $\lambda$-cyhalothrin (i.e. the males of Hc-GA were not $X^{S} y$ ). The genetic variation in

287 resistance observed in the Hc-GA population is likely related to the proportion of susceptible

288 adults produced by pairings of heterozygous females $\left(X^{R} X^{S}\right)$ and resistant males $\left(X^{R} y\right)$

289 (Tables 4 and 5). Families of the susceptible population (Hc-CA), the progeny of $\mathrm{F}_{1} \mathrm{SR}$ and

290 the backcrosses BC3 and BC4 exhibited responses aligned with the expected frequency of

291 susceptible offspring (1.00) (Tables 4 and 5). Families of $F_{1} R S$ were similar to one another in

292 knockdown $(\mathrm{P}=0.6611)$ and mortality $(\mathrm{P}=0.0948)$. Furthermore, the proportion of

293 individuals exhibiting knockdown and mortality was significantly different from the expected

294 proportion in three of the four families (Tables 4 and 5), evidencing genetic variation for

295 knockdown $\left(\chi^{2}=30.23, \mathrm{P}<0.0001, \mathrm{df}=4\right)$ and mortality $\left(\chi^{2}=25.35, \mathrm{P}<0.0001, \mathrm{df}=4\right)$. 
296 Variation was observed among families of BC2 ( $\odot$ Hc-GA x $\curvearrowright F_{1}$ SR) for knockdown $\left(\chi^{2}=\right.$

$29726.55, \mathrm{P}<0.0001, \mathrm{df}=5)$, but not for mortality $\left(\chi^{2}=0.55, \mathrm{P}=0.9932, \mathrm{df}=5\right)$. Variation for

298 the knockdown effect was observed for only two out of five families (Table 4). Regardless of

299 individual family outcome, there was no difference among BC2 families based on knockdown

$300(\mathrm{P}=0.3277)$ or mortality $(\mathrm{P}=0.9942)$. For the backcross $\mathrm{BC} 1\left(q \mathrm{Hc}-\mathrm{GA} \times \AA \mathrm{F}_{1} \mathrm{RS}\right)$, the

301 high variability among families and variation from the expected response confirm the genetic

302 variation of their parental resistant population (Hc-GA).

303

\section{4. Discussion}

305 Resistance in $H$. convergens to $\lambda$-cyhalothrin was confirmed in a Georgia population, 306 and it appears to have multiple mechanisms that also may differ in inheritance. Based on 307 knockdown response $\left(\mathrm{KD}_{50}\right)$, the resistance seems to be autosomally inherited and 308 incompletely recessive, but based on $\mathrm{KD}_{90}$ the inheritance also appears to be sex-linked. Sex309 linked inheritance of resistance is also indicated based on lethal dose (LD) results calculated 310 for $F_{1}$ progenies $24 \mathrm{~h}$ post-treatment. Several factors might contribute to the variability 311 observed in types of responses, including presence of heterozygotes in the parental population 312 causing unexpected genetic variation in reciprocal crosses (see below) and resulting in dose313 mortality curve slopes approaching 1.0 [44]. In addition, we cannot disregard genetic 314 differences of the two studied populations that probably also affect our results.

315 The metabolism of $\lambda$-cyhalothrin has at least one resistance mechanism in $H$. 316 convergens, as indicated by the action of the synergist PBO in significantly decreasing 317 resistance in the GA population. The estimated KDs and LDs were reduced by adding PBO to $318 \lambda$-cyhalothrin for the resistant population. Recovery from knockdown by $24 \mathrm{~h}$ post-treatment 319 was reduced by approximately $2 / 3$ with addition of $\mathrm{PBO}$, and a similar reduction was 320 observed in the LD responses (Table 2). However, resistance in the Hc-GA population was 
321 not fully suppressed by PBO - resistance in this population was still approximately 70 times 322 that of Hc-CA after PBO was added. Thus, considering that the resistance was not fully 323 inhibited with PBO, further studies are needed to identify the other mechanism(s) present.

324 The hypothesis of sex-linked inheritance should be accepted if the KD and LD 325 calculated for backcrosses $\mathrm{BC} 1$ and $\mathrm{BC} 2$ are similar to the resistant Hc-GA population and $\mathrm{F}_{1}$ $326 \mathrm{RS}$, respectively, and if the KDs and LDs of backcrosses $\mathrm{BC} 3$ and $\mathrm{BC} 4$ are similar to those of 327 the $\mathrm{F}_{1}$ SR progenies and the susceptible population (Hc-CA), respectively. Only the KDs and 328 LDs of BC2 and BC4 differed from the expected result. However, the limited differences 329 observed also suggest presence of genetic variation [45] or possible natural variation [46] 330 (Table 1). Furthermore, bioassays of single-paired crosses with the discriminating dose of $\lambda$ 331 cyhalothrin clearly indicated sex-linked inheritance for both knockdown (KDs) and mortality 332 (LDs) (Table 5). Additionally, the resistance phenotype of males carrying $\mathrm{X}^{\mathrm{R}}$-chromosome 333 yielded responses similar to those of females that were $X^{R} X^{R}$. Finally, estimates of the 334 minimum number of genes responsible for $\lambda$-cyhalothrin resistance in $H$. convergens based on 335 KDs and LDs also support sex linkage as the model of inheritance. Sex linkage inheritance 336 patterns tend to inflate phenotypic variances that are critical for estimating the number of 337 genes governing the trait [42]. This inflated variance confounds accurately estimating the 338 number of genes underlying the response, yielding results such as the negative gene estimated 339 values for the $\mathrm{F}_{1}$ progenies obtained in this study.

340 The knockdown responses indicate that $\lambda$-cyhalothrin resistance in $H$. convergens is 341 inherited as a recessive trait. Thus, the difference in degree of dominance for the sex-linked 342 response is independent of the survival of the heterozygotes in $\mathrm{F}_{1}$ RS progeny (dominant) and 343 mortality in the $\mathrm{F}_{1}$ SR progeny (recessive) [47]. The difference is a result of varying mortality 344 patterns between the offspring of the $F_{1} S R$ reciprocal cross compared to $F_{1} S R$. Male $F_{1} R S$ 345 progeny would be resistant $\left(X^{R} y\right)$, while female progeny would be susceptible $\left(X^{R} X^{S}\right)$. In 
346 contrast, both male $\left(X^{S} y\right)$ and female $\left(X^{R} X^{S}\right) F_{1}$ SR progeny would be susceptible. In this 347 way, the presence of resistant males in $F_{1} R S$ population inflates the $K D$ and $L D$ values, 348 affecting degree of dominance for each reciprocal cross depending on the magnitude of the 349 response for resistant individuals.

The mortality data for $\mathrm{F}_{1} \mathrm{RS}$ progeny did not fit the Probit model, indicating that the Hc-

351 GA population was not homozygous for resistance. Assaying for homozygosity revealed 352 presence of $X^{R} X^{S}$ females in the Hc-GA population. Despite the heterozygosity in the Hc-GA 353 population, it was not the only influencing factor because the KD for $\mathrm{F}_{1} \mathrm{RS}$ progeny fit the 354 Probit model. Some individuals of the $\mathrm{F}_{1} \mathrm{SR}$ progeny, as well as resistant individuals from Hc355 GA, recovered from knockdown (2h) during the $24 \mathrm{~h}$ post-treatment mortality evaluation in 356 the bioassay of dose-mortality. The results from single-pair families demonstrated that the 357 gene influencing recovery from treatment might be also sex-linked, as males and females of $358 \mathrm{~F}_{1} \mathrm{SR}$ and females of $\mathrm{F}_{1} \mathrm{RS}$ did not recover $24 \mathrm{~h}$ after treatment. However, the degree of 359 dominance was not conclusive because the discriminatory dose used in the single-pair cross 360 bioassay was sufficiently high to yield functionally recessive inheritance. Thus, a sex linkage 361 model can yield varying results for the resistance mechanisms.

362 Our results indicate that heterozygous Hc-GA females $\left(\mathrm{X}^{\mathrm{R}} \mathrm{X}^{\mathrm{S}}\right)$ used in the $\mathrm{F}_{1} \mathrm{RS}$ 363 reciprocal cross can produce susceptible males $\left(\mathrm{X}^{\mathrm{S}} \mathrm{y}\right)$. The presence of susceptible males in 364 such a cross would not be anticipated for the offspring of reciprocal crosses $\left(\mathrm{F}_{1} \mathrm{RS}\right)$ if the 365 parental populations are homozygous susceptible $\left(\mathrm{X}^{\mathrm{S}} \mathrm{X}^{\mathrm{S}}\right.$ and $\left.\mathrm{X}^{\mathrm{S}} \mathrm{y}\right)$ or resistant $\left(\mathrm{X}^{\mathrm{R}} \mathrm{X}^{\mathrm{R}}\right.$ and $366 \mathrm{X}^{\mathrm{R}} \mathrm{y}$ ), based on an "Xyp" sex determination system. Presence of susceptible males might 367 generate unusually low LDs and the conclusion that resistance is autosomally inherited. This 368 occurred with a heterogeneous population of Cydia pomonella (L.) (Lepidoptera: Tortricidae) 369 tested for resistance to the CpGV (Baculoviridae), and resistance was originally characterized 370 as autosomally inherited [48]. However, after selection in the laboratory, single-pair 
371 experiments with the selected homozygous-resistant $C$. pomonella population revealed that 372 inheritance was sex-linked [33]. Results from single-pair experiments with a heterozygous

373 population of $C$. pomonella, similar to our experiments, supported sex-linked inheritance for 374 resistance [49]. Based on the slopes of the dose-mortality curves calculated for $F_{1} R S$ and $F_{1}$ 375 SR, there is also support for sex-linked heritability of resistance in $H$. convergens similar to $C$. 376 pomonella [49].

377 Numerous studies have reported recessive inheritance for pyrethroid resistance in 378 different groups of insects. However, sex-linked inheritance of resistance is not common 379 compared to autosomal inheritance. These results add to the reported cases of sex-linked 380 inheritance of resistance: Sitophilus oryzae L. (Col.: Curculionidae) [50], Culex 381 quinquefasciatus Say [51], Sitophilus zeamais Mots. [52], Spodoptera littoralis Boisduval 382 (Lepidoptera: Noctuidae) [53], Helicoverpa armigera Hübner [54], Leptinotarsa 383 decemlineata (Say) (Coleoptera: Chrysomelidae) [55], Grapholita molesta (Busck) 384 (Lepidoptera: Tortricidae) [56], and C. pomonella [33].

385 When $\lambda$-cyhalothrin is applied in high doses to resistant $H$. convergens, the effective 386 dominance is best characterized as recessive, but at lower doses it is functionally dominant. 387 This pattern of dominance has been reported in other insects [32, 57, 58, 59, 60, 61, 62]. 388 Dominance is not an intrinsic trait of one allele [63], as its expression is dependent on the 389 dose applied [47]. Thus, when a dose is sufficiently high to kill all heterozygotes in the 390 population, the resistance can be functionally recessive, as described by Curtis et al. [64]. On 391 the other hand, at low doses in which the heterozygotes survive, resistance would be 392 characterized as functionally dominant. Numerically, we found no functionally recessive 393 response for $F_{1}$ RS progeny at high doses of $\lambda$-cyhalothrin. This can be explained by 394 inheritance driven by sex linkage due to the presence of $X^{R} y$ males. 
Resistance of $H$. convergens to $\lambda$-cyhalothrin was likely selected by historically

396

397

398

399

400

401

402

403

404

405

406

407

408

409

410

411

412

widespread and intensive insecticide use in Georgia crop systems where the beetles regularly occurred. Using cotton as an example, DDT was widely used during the 1950's to control boll weevil and bollworms in cotton [65]. DDT was replaced with organophosphates (OPs) after DDT resistance was detected in boll weevil [66]. Detection of bollworms resistant to OPs [67] led, in turn, to wide and frequent use of pyrethroid insecticides in Georgia to control this group of pests in the 1980's [68]. The persistence of boll weevil in cotton required repeated applications of broad-spectrum insecticides beginning as early as the appearance of the first flower bud and continuing until close to harvest, producing prolonged negative effects on natural enemy populations [69]. Thus, the historically intensive use of DDT, OPs, and pyrethroids in cotton fields, as well as other surrounding crops frequented by $H$. convergens (e.g., pecans, tobacco, corn), would have applied significant selection pressure to $H$. convergens populations for resistance. Even after pesticide use was dramatically reduced by widespread adoption of Bt-transgenic cotton resistant to lepidopteran pests and following eradication of the boll weevil in Georgia [69, 70], pyrethroids and OPs continue to be applied for stink bugs and other pests [71]. The recently reduced application frequency of pyrethroids and OPs to cotton likely reduced the negative effect on $H$. convergens populations and, therefore, permitted resistance-conferring genes to be fixed in the population, affording the stability typical of pyrethroid resistance.

Unlike the case with autosomally inherited resistance, sex linkage allows males of $H$. convergens to exhibit resistance to $\lambda$-cyhalothrin even when the allele is present at low levels, because they need only a single resistant allele to confer complete resistance. This capacity may facilitate persistence and rapid spread of the resistant allele(s) in the population. Information on factors that usually influence resistance, such as initial allele frequency in the field population, population size, sex ratio in the field, adaptive costs of resistance, migration, 
420 and polyandry in $H$. convergens are needed to better understand evolution of the resistance in

421 this important natural enemy species. However, initial results of resistance selection in Hc-GA

422 under laboratory conditions suggest rapid evolution of resistance can occur, as described for

423 recessive and sex-linked inherited resistance [54]. Variables, such as high frequency of the

424 allele for resistance, heterozygote female $X^{R} X^{S}$ being susceptible to $\lambda$-cyhalothrin and being

425 killed in the progeny, males requiring only one allele to survive the insecticide application,

426 and the interaction of resistance mechanisms driving the survival of susceptible individuals to

427 the insecticide application, can pace the evolution of resistance in $H$. convergens. Despite the

428 likelihood of multiple genes governing resistance of $H$. convergens to $\lambda$-cyhalothrin, the

429 nature of the interactions among these genes was not studied. The interaction among factors

430 governing inheritance of resistance is complex to define [72], but studies focusing on the role

431 of the multiple genes in resistance, the adaptive costs to maintain multiple resistance genes in

432 the absence of insecticide pressure, and the benefits of different resistance mechanisms in the

433 studied species are open avenues for investigation. For instance, we treated adults of Hc-GA

434 and Hc-CA with 10-fold the field rate of the organophosphate dicrotophos and the results

435 showed $100 \%$ and $0 \%$ survival for these two populations, respectively.

436 In conclusion, the inheritance of $\lambda$-cyhalothrin resistance in $H$. convergens is sex-linked

437 and recessive. Likely, the major mechanism of the resistance involves insensitivity of a kdr-

438 type target site, with participation of detoxifying enzymes, which were partially inhibited by

439 PBO leading to greater susceptibility of the resistant population (Hc-GA). These results differ

440 from those obtained for another lady beetle species, E. connexa, that exhibits resistance to the

$441 \lambda$-cyhalothrin, but in which resistance is autosomally inherited and incompletely dominant,

442 and which was fully inhibited with PBO with high activity of esterase (A.R.S.R. unpublished

443 data). Further, the $\mathrm{LD}_{50}$ and $\mathrm{LD}_{90}$ for the Hc-GA population (0.816 and $\left.4.595 \mathrm{~g}\right)$ are greater

444 than the highest recommended field rate of $\lambda$-cyhalothrin for cotton (44 $\mathrm{g}$ of a.i/ha at 100 
L/ha) Roberts et al. [73], indicating the possibility of effectively integrating these predators

446 with pyrethroid insecticides.

\section{Acknowledgments}

This research was supported in part by Georgia Cotton Commission funding to J.R.R., and

CNPq (Edital Universal - Processo 473211/2009-2) to J.B.T. Also, A.R.S.R. gives special

thanks to 'Coordenação de Aperfeiçoamento de Pessoal de Nível Superior' (CAPES

454 Foundation, Brazil, PDEE-BEX 7095/10-4).

\section{References}

[1] V.M. Stern, R.R.F. Smith, R. van den Bosch, K.S. Hagen, The integrated control concept, Hilgardia 29 (1959) 81-101.

[2] A.K. Pathan, A.H. Sayyed, M. Aslam, M. Razaq, G. Jilani, M.A. Saleem, Evidence of field-evolved resistance to organophosphates and pyrethroids in Chrysoperla carnea (Neuroptera: Chrysopidae), J. Econ. Entomol. 101 (2008) 1676-1684.

[3] S. Blümel, G.A. Matthews, A. Grinstein, Y. Elad, Pesticides in IPM: selectivity, sideeffects, application and resistance problems, in: R. Albajes, M.L. Gullino, J.C. van Lenteren, Y. Elad. (Eds.), Integrated pest and disease management in greenhouse crops, Kluwer Academic Publishers, The Netherlands, 2000, pp. 150-167.

[4] N. Desneux, A. Decourtye, J.-M. Delpuech, The sublethal effects of pesticides on beneficial arthropods, Annu. Rev.Entomol. 52 (2007): 81-106.

[5] Ruberson, J.R., H. Nemoto, Y. Hirose, Pesticides and conservation of natural enemies in pest management, in: P. Barbosa (Ed.), Conservation biological control, Academic Press, New York, 1998, pp. 207-220.

[6] J.J. Obrycki, J.D. Harwood, T.J. Kring, R.J. O’Neil, Aphidophagy by Coccinellidae: application of biological control in agroecosystems, Biol. Control 51 (2009) 244-254.

[7] M.E. Whalon, D. Mota-Sanchez, R.M. Hollingworth, L. Duynslager. 2012. Arthropod Pesticide Resistance Database. http://www.pesticideresistance.org/search/1. (accessed on 25 May 2012).

[8] B.A. Croft, A.W.A. Brown, S.A. Hoying, Organophosphorus resistance and its inheritance in the predaceous mite, J. Econ. Entomol. 69 (1976) 64-68. 
[9] D. Suckling, J.T.S. Walker, P.W. Shaw, N.P. Markwick, G.C.H. Wearing, Management of resistance in horticultural pests and beneficial species in New Zealand, Pestic. Sci. 23 (1988) 157-164.

[10] H.J. Whitten, M.A. Hoy, Genetic improvement and other genetic considerations for improving the efficacy and success rate of biological control, in: T.S. Bellows, T.W. Fisher (Eds), Handbook of biological control, Academic Press, New York, 1999, pp. 271-296.

[11] J.E. Baker, Stability of malathion resistance in two hymenopterous parasitoids, J. Econ. Entomol. 88 (1995) 232-236.

[12] E.E. Grafton-Cardwell, M.A. Hoy, Short-term effects of permethrin and fenvalerate on oviposition by Chrysoperla carnea (Neuroptera: Chrysopidae), J. Econ. Entomol. 78 (1985) 955-959.

[13] A.K. Pathan, A.H. Sayyed, M. Aslam, T.-X. Liu, M. Razzaq, W.A. Gillani, Resistance to pyrethroids and organophosphates increased fitness and predation potential of Chrysoperla carnea (Neuroptera: Chrysopidae), J. Econ. Entomol. 103 (2010) 823-834.

[14] A.H. Sayyed, A.K. Pathan, U. Faheem, Cross-resistance, genetics and stability of resistance to deltamethrin in a population of Chrysoperla carnea from Multan, Pakistan, Pestic. Biochem. Physiol. 98 (2010) 325-332.

[15] I. Hodek, A. Hońek, Ecology of Coccinellidae, Kluwer Academic Publishers, Dordrecht, 1996.

[16] J.J. Obrycki, T.J. Kring, Predaceous Coccinellidae in biological control, Annu. Rev. Entomol. 43 (1998) 295-321.

[17] I. Hodek, Biology of Coccinellidae, Academia, Prague \& W. Junk The Hague, 1973.

[18] P.D. Lingren, R.L. Ridgway, Toxicity of five insecticides to several insect predators, J. Econ. Entomol. 60 (1967) 1639-1641.

[19] H.R. Moffit, E.W. Anthon, L.O. Smith, Toxicity of several commonly used orchard pesticides to adult Hippodamia convergens, Environ. Entomol. 1 (1972) 20-23.

[20] S.R. Coats, J.R. Coats, C.R. Ellis. Selective toxicity of three synthetic pyrethroids to eight coccinellids, a eulophid parasitoid, and two pest chrysomelids, Environ. Entomol. 8 (1979) 720-722.

[21] L.A. Hull, V.R. Starner, Impact of four synthetic pyrethroids on major natural enemies and pests of apple in Pennsylvania, J. Econ. Entomol. 76 (1983) 122-130.

[22] N. Kaakeh, W. Kaakeh, G.W. Bennet, Topical toxicity of imidacloprid, fipronil, and seven conventional insecticides to the adult convergent lady beetle (Coleoptera: Coccinellidae), J. Entomol. Sci. 31 (1996) 315-322.

[23] J.R. Ruberson, P. Roberts, J.P. Michaud, Pyrethroid resistance in Georgia populations of the predator Hippodamia convergens (Coleoptera: Coccinellidae), Proc. Beltwide Cotton 
Conf. 1 (2007) 361-365.

[24] A.R.S. Rodrigues, 2012. Caracterização da resistência de joaninhas predadoras ao lambda-cialotrina. DSc. Thesis, Universidade Federal Rural de Pernambuco, Recife, Brazil.

[25] R. Head, W.W. Neel, C.R. Sartor, H. Chambers, Methyl parathion and carbaryl resistance in Chrysomela scripta and Coleomegilla maculata, Bull. Environ. Cont. Toxicol. 17 (1977) 163-164.

[26] J.B. Graves, R.B. Mohamad, D.F. Clower, Beneficial insects also developing "resistance", LA. Agric. 22 (1978) 10-11.

[27] K.S. Hagen, Biology and ecology of predacious Coccinellidae, Annu. Rev. Entomol. 7 (1962) 289-326.

[28] P.G. Tillman, J.E. Mulrooney, Effect of selected insecticides on the natural enemies Coleomegilla maculata and Hippodamia convergens (Coleoptera: Coccinellidae), Geocoris punctipes (Hemiptera: Lygaeidae), and Bracon mellitor, Cardiochiles nigriceps, and Cotesia marginiventris (Hymenoptera: Braconidae) in cotton, J. Econ. Entomol. 93 (2000) $1638-1643$.

[29] E.W. Riddick, G. Dively, P. Barbosa, Season-long abundance of generalist predators in transgenic versus non-transgenic potato fields, J. Entomol. Sci. 35 (2000) 349-359.

[30] J.B. Torres, J.R. Ruberson, Lady beetle species shift in Bt and non-Bt cotton fields, Proc. Beltwide Cotton Conf. 1 (2005a) 1630-1638.

[31] J.B. Torres, J.R. Ruberson, Canopy-and ground-dwelling predatory arthropods in commercial Bt and non-Bt cotton fields: patterns and mechanisms, Environ. Entomol. 34 (2005b) $1242-1256$.

[32] Y.-B. Liu, B.E. Tabashnik, Inheritance of resistance to the Bacillus thuringiensis toxin Cry1C in the diamondback moth, Appl. Environ. Microbiol. 63 (1997) 2218-2223.

[33] S. Asser-Kaiser, E. Fritsch, K. Undorf-Spahn, J. Kienzle, K.E. Eberle, N.A. Gund, A. Reineke, C.P.W. Zebitz, D.G. Heckel, J. Huber, J.A. Jehlel, Rapid emergence of baculovirus resistance in codling moth due to dominant, sex-linked inheritance, Science 317 (2007) 1916-1918.

[34] S.G. Smith, Chromosome numbers of Coleoptera. II, Can. J. Genet. Cytol. 2 (1960) 6688.

[35] LeOra Software, POLO-PC: a user's guide to Probit-Logit analysis, Berkley, LeOra Software, 1987.

[36] D.J. Finney, Probit analysis, Cambridge University Press, London, 1971.

[37] J.L. Robertson, H.K. Preisler, Pesticide bioassays with arthropods, First ed., CRC Press, Boca Raton, 1992. 
[38] B.F. Stone, A formula for determining the degree of dominance in cases of monofactorial inheritance of resistance to chemicals. Bull. W.H.O. 38 (1968) 325-326.

[39] E.L. Lehmann, Testing statistical hypotheses, Wiley, New York, 1966.

[40] H.K. Preisler, M.A. Hoy, J.L. Robertson, Statistical analysis of modes of inheritance for pesticide resistance, J. Econ. Entomol. 83 (1990) 1649-1655.

[41] D.L. Hartl, A primer of population genetics, Second ed., Sinauer Associates, Sunderland, Mass. 1992.

[42] R. Lande, The minimum number of genes contributing to quantitative variation between and within populations, Genetics 99 (1981) 541-553.

[43] R. Sokal, F. Rohlf, Biometry: the principles and practice of statistics in biological research. W.H. Freeman, San Francisco, 1981.

[44] J.L. Robertson, R.M. Russel, H.K. Preisler, N.E. Savin, Pesticide resistance, in: Bioassays with arthropods. CRC Press, Boca Raton, 2007, pp. 99-114.

[45] B.E. Tabashnik, Determining the mode of inheritance of pesticide resistance with backcross experiments, J. Econ. Entomol. 81 (1991) 703-712.

[46] J.L. Robertson, H.K. Preisler, S.S. Ng, L.A. Hickle, W.D., Gelernter, Natural variation a complicating factor in bioassays with chemical and microbial pesticides, J. Econ. Entomol. 88 (1995) 1-10.

[47] D. Bourguet, A. Genissel, M. Raymond, Insecticide resistance and dominance levels, J. Econ. Entomol. 93 (2000) 1588-1595.

[48] K.E. Eberle, J.A. Jehle, Field resistance of codling moth against Cydia pomonella granulovirus $(\mathrm{CpGV})$ is autosomal and incompletely dominant inherited, J. Invertebr. Pathol. 93 (2006) 201-206.

[49] S. Asser-Kaiser, D.G. Heckel, J.A. Jehle, Sex linkage of CpGV resistance in a heterogeneous field strain of the codling moth Cydia pomonella (L.), J. Invertebr. Pathol. 103 (2010) 59-64.

[50] N.W. Heather, Sex-linked resistance to pyrethroids in Sitophilus oryzae (L.) (Coleoptera: Curculionidae), J. Stored Prod. Res. 22 (1986) 15-20.

[51] P.T. McDonald, C.D. Schmidt, Genetics of permethrin resistance in the hornfly (Diptera: Muscidae), J. Econ. Entomol. 80 (1987) 433-437.

[52] R.N.C. Guedes, J.O.G. Lima, J.P. Santos, C.D. Cruz, Inheritance of deltamethrin resistance in a Brazilian strain of maize weevil (Sitophilus zeamais Mots.), Int. J. Pest Manag. 40 (1994) 103-106.

[53] J. Chaufaux, J. Müller-Cohn, C. Buisson, V. Sanchis, D. Lereclus, N. Pasteur, Inheritance of resistance to the Bacillus thuringiensis Cry IC toxin in Spodoptera littoralis 
(Lepidoptera: Noctuidae), J. Econ. Entomol. 90 (1997) 873-878.

[54] J.C. Daly, J.H. Fisk, Sex-linked inheritance of endosulfan resistance in Helicoverpa armigera, Heredity 81 (1998) 55-62.

[55] P.A. Follet, F. Gould, G.C. Kennedy, High-realism model of Colorado potato beetle (Coleoptera: Chrysomelidae) adaptation to permethrin, Environ. Entomol. 24 (1995) 167178.

[56] L.H.B. Kanga, D.J. Pree, F.W. Plapp Jr., J.L. van Lier, Sex-linked altered acetylcholinesterase resistance to carbamate insecticides in adults of the oriental fruit moth, Grapholita molesta (Lepidoptera: Tortricidae), Pestic. Biochem. Physiol. 71 (2001) 29-39.

[57] A.H. Sayyed, R. Haward, S. Herrero, J. Ferré, D.J. Wright, Genetic and biochemical approach for characterization of resistance to Bacillus thuringiensis toxin Cry1 Ac in a field population of the diamondback moth, Plutella xylostella, Appl. Environ. Microbiol. 66 (2000) 1509-1516.

[58] J.-Z. Zhao, H.L. Collins, J.D. Tang, J. Cao, E.D. Earle, R.T. Roush, S. Herrero, B. Escriche, J. Ferré, A.M. Shelton, Development and characterization of diamondback moth resistance to transgenic broccoli expressing high levels of Cry1C, Appl. Environ. Microbiol. 66 (2000) 3784-3789.

[59] A.P. Alves, T.A. Spencer, B.E. Tabashnik, B.D. Siegfried, Inheritance of resistance to the Cry1Ab Bacillus thuringiensis toxin in Ostrinia nubilalis (Lepidoptera: Crambidae), J. Econ. Entomol. 99 (2006) 494-501.

[60] V. Balasubramani, A.H. Sayyed, N. Crickmore, Genetic characterization of resistance to deltamethrin in Plutella xylostella (Lepidoptera: Plutellidae) from India, J. Econ. Entomol. 101 (2008) 1911-1918.

[61] A.H. Sayyed, S. Saeed, M. Noor-Ul-Ane, N. Crickmore, Genetic, biochemical, and physiological characterization of spinosad resistance in Plutella xylostella (Lepidoptera: Plutellidae), J. Econ. Entomol. 101 (2008) 1658-1666.

[62] S.A. Shad, A.H Sayyed, M.A. Saleem, Cross-resistance, mode of inheritance and stability of resistance to emamectin in Spodoptera litura (Lepidoptera: Noctuidae), Pestic. Manag. Sci. 66 (2010) 839-846.

[63] J.A. Sved, O. Mayo, The evolution of dominance, in: K.-I. Kojima (Ed.), Mathematical topics in population genetics, Springer, Berlin, 1970, pp. 289-316.

[64] C.F. Curtis, Cook, L.M., R.J. Wood, Selection for and against insecticide resistance and possible methods of inhibiting the evolution of resistance in mosquitoes, Ecol. Entomol. 3 (1978) 273-287.

[65] Anonymous. 1950. Cotton insects, in: Anonymous (Ed.), Georgia agricultural handbook, Univ. of Georgia Coop. Ext. Serv. Publ., Athens, p. 318.

[66] Anonymous. 1958. Cotton insects, in: Anonymous (Ed.), Georgia agricultural handbook. 
Univ. of Georgia Coop. Ext. Serv. Publ., Athens, pp. 105-107.

[67] T.D. Canerday, Response of bollworm and tobacco budworm in Georgia to methyl parathion, J. Econ. Entomol. 67 (1974) 299.

[68] W.R. Lambert, Cotton insect control, in: Anonymous (Ed.), The 1981 Georgia farm chemical handbook, Univ. Georgia Coop. Ext. Serv. Publ., Athens,1981, pp. 39-41.

[69] P.B. Haney, W.J. Lewis, W.R. Lambert, 2009. Cotton production and the boll weevil in Georgia: history, cost of control, and benefits of eradication. College of Agricultural and Environmental Sciences, The University of Georgia, Athens, GA, 60p. (Research Bulletin 428).

[70] F.S. Betz, B.G. Hammond, R.L. Fuchs, Safety and advantages of Bacillus thuringiensisprotected plants to control insect pests, Regul. Toxicol. Pharmacol. 32 (2000) 156-173.

[71] J.K. Greene, S.G. Turnipseed, M.J. Sullivan, O.L. May, Treatment thresholds for stink bugs (Hemiptera: Pentatomidae) in cotton, J. Econ. Entomol. 94 (2001) 403-409.

[72] M.C. Hardstone, C.A. Leichter, J.G. Scott, Multiplicative interaction between the two major mechanisms of permethrin resistance, $k d r$ and cytochrome P450-monooxygenase detoxification, in mosquitoes, J. Evol. Biol. 22 (2009) 416-423.

[73] P.M. Roberts, J.R. Ruberson, M. Toews, Cotton, in: P. Guillebau (Ed.), Georgia pest management handbook 2011, Univ. of Georgia Coop. Ext. Serv. Publ., Athens, 2011, pp. 64-101. 
Table 1. Knockdown and mortality responses of Hippodamia convergens susceptible (Hc-CA) and resistant (Hc-GA) populations, F1 progeny from reciprocal crosses and from

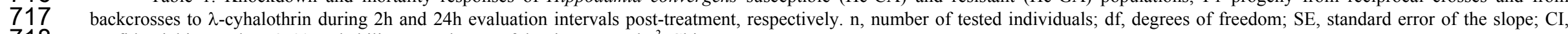

718 confidential intervals at $95 \%$ probability; DD, degree of dominance; and $\chi^{2}$, Chi-square test.

\begin{tabular}{|c|c|c|c|c|c|c|c|c|c|c|}
\hline $\begin{array}{l}\text { Population or } \\
\text { Progeny }^{\mathrm{a}}\end{array}$ & $\mathrm{n}$ & df & Slope \pm SE & $\begin{array}{c}\mathrm{KD}_{50} \\
\left(\mathrm{CI}_{95 \%}\right)^{\mathrm{b}}\end{array}$ & $\begin{array}{c}\mathrm{RR}_{50} \\
\left(\mathrm{CI}_{95 \%}\right)^{\mathrm{c}}\end{array}$ & $\mathrm{DD}_{50} \pm \mathrm{SE}$ & $\begin{array}{c}\mathrm{KD}_{90} \\
\left(\mathrm{CI}_{95 \%}\right)^{\mathrm{b}}\end{array}$ & $\begin{array}{c}\mathrm{RR}_{90} \\
\left(\mathrm{CI}_{95 \%}\right)^{\mathrm{c}}\end{array}$ & $\mathrm{DD}_{90} \pm \mathrm{SE}$ & $\chi^{2}$ \\
\hline \multicolumn{11}{|c|}{ Knockdown - $2 h$ evaluation } \\
\hline $\mathrm{Hc}-\mathrm{CA}$ & 191 & 4 & $2.39 \pm 0.42$ & $\begin{array}{c}0.001 \\
(0.0004-0.002)\end{array}$ & - & & $\begin{array}{c}0.004 \\
(0.002-0.011)\end{array}$ & - & & 6.76 \\
\hline Hc-GA & 221 & 4 & $1.73 \pm 0.28$ & $\begin{array}{c}0.297 \\
(0.156-0.439)\end{array}$ & $\begin{array}{c}286.75 \\
(86.59-949.64)\end{array}$ & & $\begin{array}{c}1.636 \\
(0.955-6.219)\end{array}$ & $\begin{array}{c}461.16 \\
(133.26-1595.93)\end{array}$ & & 4.76 \\
\hline $\mathrm{F}_{1} \mathrm{RS}$ & 214 & 5 & $1.10 \pm 0.20$ & $\begin{array}{c}0.012 \\
(0.005-0.021)\end{array}$ & $\begin{array}{c}11.91 \\
(5.43-26.11)\end{array}$ & $-0.13 \pm 0.15$ & $\begin{array}{c}0.182 \\
(0.105-0.474)\end{array}$ & $\begin{array}{c}51.11 \\
(24.04-108.68)\end{array}$ & $0.27 \pm 0.17$ & 4.50 \\
\hline $\mathrm{F}_{1} \mathrm{SR}$ & 220 & 4 & $1.52 \pm 0.19$ & $\begin{array}{c}0.003 \\
(0.0002-0.007)\end{array}$ & $\begin{array}{c}2.62 \\
(0.57-12.02)\end{array}$ & $-0.66 \pm 0.27$ & $\begin{array}{c}0.019 \\
(0.009-0.038)\end{array}$ & $\begin{array}{c}5.35 \\
(2.81-10.16)\end{array}$ & $-0.48 \pm 0.11$ & 0.50 \\
\hline $\mathrm{BC} 1$ & 198 & 6 & $1.32 \pm 0.19$ & $\begin{array}{c}0.271 \\
(0.162-1.14)\end{array}$ & $\begin{array}{c}211.33 \\
(111.96-398.90)\end{array}$ & & $\begin{array}{c}2.254 \\
(1.02-15.43)\end{array}$ & $\begin{array}{c}835.24 \\
(252.59-2761.92)\end{array}$ & & 6.35 \\
\hline $\mathrm{BC} 2$ & 167 & 4 & $0.72 \pm 0.20$ & $\begin{array}{c}0.073 \\
(0.026-0.144)\end{array}$ & $\begin{array}{c}70.47 \\
(31.19-159.24)\end{array}$ & & $\begin{array}{c}4.480 \\
(1.100-396.1)\end{array}$ & $\begin{array}{c}1259.04 \\
(143.76-11026.3)\end{array}$ & & 6.33 \\
\hline $\mathrm{BC} 3$ & 267 & 8 & $2.27 \pm 0.33$ & $\begin{array}{c}0.003 \\
(0.002-0.004)\end{array}$ & $\begin{array}{c}2.81 \\
(1.71-4.63)\end{array}$ & & $\begin{array}{c}0.011 \\
(0.008-0.017)\end{array}$ & $\begin{array}{c}3.00 \\
(1.85-4.89)\end{array}$ & & 4.78 \\
\hline $\mathrm{BC} 4$ & 268 & 8 & $2.63 \pm 0.40$ & $\begin{array}{c}0.003 \\
(0.002-0.004)\end{array}$ & $\begin{array}{c}2.91 \\
(1.80-4.71)\end{array}$ & & $\begin{array}{c}0.009 \\
(0.007-0.014)\end{array}$ & $\begin{array}{c}2.61 \\
(1.64-4.14)\end{array}$ & & 1.78 \\
\hline \multicolumn{4}{|c|}{ Mortality -24 h evaluation } & $\mathrm{LD}_{50}$ & & & $\mathrm{LD}_{90}$ & & & \\
\hline $\mathrm{Hc}-\mathrm{CA}$ & 191 & 4 & $2.12 \pm 0.33$ & $\begin{array}{c}0.004 \\
(0.003-0.005)\end{array}$ & - & & $\begin{array}{c}0.015 \\
(0.010-0.028)\end{array}$ & - & & 1.24 \\
\hline Hc-GA & 221 & 4 & $1.71 \pm 0.32$ & $\begin{array}{c}0.816 \\
(0.631-1.167)\end{array}$ & $\begin{array}{c}220.03 \\
(76.89-629.65)\end{array}$ & & $\begin{array}{c}4.595 \\
(2.54-15.53)\end{array}$ & $\begin{array}{c}308.00 \\
(79.62-1191.39)\end{array}$ & & 1.54 \\
\hline $\mathrm{F}_{1} \mathrm{RS}$ & 214 & 5 & $1.17 \pm 0.17$ & $\begin{array}{c}0.194 \\
(0.059-1.745)\end{array}$ & $\begin{array}{c}52.33 \\
(32.30-84.80)\end{array}$ & $0.47 \pm 0.16$ & $\begin{array}{c}2.423 \\
(0.545-14490)\end{array}$ & $\begin{array}{c}162.29 \\
(56.64-465.02)\end{array}$ & $0.78 \pm 0.26$ & $19.63 *$ \\
\hline $\mathrm{F}_{1} \mathrm{SR}$ & 220 & 4 & $2.19 \pm 0.33$ & $\begin{array}{c}0.026 \\
(0.019-0.034)\end{array}$ & $\begin{array}{c}7.03 \\
(4.89-10.11)\end{array}$ & $-0.28 \pm 0.09$ & $\begin{array}{c}0.100 \\
(0.072-0.173)\end{array}$ & $\begin{array}{c}6.73 \\
(3.62-12.52)\end{array}$ & $-0.34 \pm 0.12$ & 1.46 \\
\hline $\mathrm{BC} 1$ & 198 & 6 & $2.03 \pm 0.39$ & $\begin{array}{c}0.804 \\
(0.548-1.441)\end{array}$ & $\begin{array}{c}216.95 \\
(131.14-358.92)\end{array}$ & & $\begin{array}{c}3.431 \\
(1.793-12.971)\end{array}$ & $\begin{array}{c}230.03 \\
(85.46-619.16)\end{array}$ & & 1.03 \\
\hline $\mathrm{BC} 2$ & 167 & 4 & $1.45 \pm 0.22$ & $\begin{array}{c}0.364 \\
(0.245-0.621)\end{array}$ & $\begin{array}{c}98.08 \\
(59.26-162.32)\end{array}$ & & $\begin{array}{c}2.754 \\
(1.346-9.637)\end{array}$ & $\begin{array}{c}184.56 \\
(65.92-516.78)\end{array}$ & & 4.58 \\
\hline $\mathrm{BC} 3$ & 267 & 8 & $2.17 \pm 0.25$ & $\begin{array}{c}0.015 \\
(0.012-0.019)\end{array}$ & $\begin{array}{c}4.07 \\
(2.90-5.71)\end{array}$ & & $\begin{array}{c}0.059 \\
(0.043-0.091)\end{array}$ & $\begin{array}{c}3.93 \\
(2.19-7.08)\end{array}$ & & 4.78 \\
\hline $\mathrm{BC} 4$ & 268 & 8 & $2.24 \pm 0.27$ & $\begin{array}{c}0.011 \\
(0.009-0.014)\end{array}$ & $\begin{array}{c}3.05 \\
(2.17-4.27)\end{array}$ & & $\begin{array}{c}0.042 \\
(0.031-0.065)\end{array}$ & $\begin{array}{c}2.83 \\
(1.58-5.08)\end{array}$ & & 4.20 \\
\hline
\end{tabular}

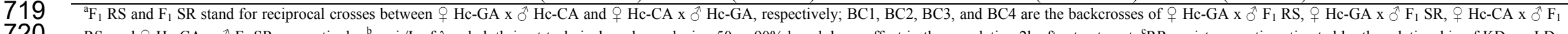

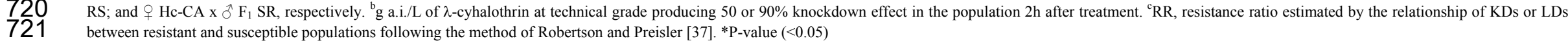


Table 2. Knockdown (2h) and mortality (24h) responses of Hippodamia convergens (Hc) populations from California (CA) and Georgia (GA) to $\lambda$-cyhalothrin (99.5\% technical grade) only or with $10 \mathrm{ppm}$ of piperonyl butoxide (PBO) added to the solution. $\mathrm{n}$. number of tested adults; $\mathrm{df}=$ degree of freedom; $\mathrm{SE}=$ standard error for the slope; $\mathrm{LDs}=$ lethal doses in $\mathrm{g}$ of a.i. $/ \mathrm{L} ; \mathrm{CI}=95 \%$ confidence intervals; and $\chi^{2}=$ chisquare test.

\begin{tabular}{|c|c|c|c|c|c|c|c|c|c|c|}
\hline $\begin{array}{l}\text { Population/ } \\
\text { Progeny }\end{array}$ & $\mathrm{n}$ & $\mathrm{df}$ & Slope \pm SE & $\begin{array}{c}\mathrm{LD}_{50} \\
\left(\mathrm{CI}_{95 \%}\right)^{\mathrm{a}}\end{array}$ & $\begin{array}{c}\mathrm{SR}_{50} \\
\left(\mathrm{CI}_{95 \%}\right)^{\mathrm{b}}\end{array}$ & $\begin{array}{c}\mathrm{RR}_{50} \\
\left(\mathrm{CI}_{95 \%}\right)^{\mathrm{c}}\end{array}$ & $\begin{array}{c}\mathrm{LD}_{90} \\
\left(\mathrm{CI}_{95 \%}\right)^{\mathrm{a}}\end{array}$ & $\begin{array}{c}\mathrm{SR}_{90} \\
\left(\mathrm{CI}_{95 \%}\right)^{\mathrm{b}}\end{array}$ & $\begin{array}{c}\mathrm{RR}_{90} \\
\left(\mathrm{CI}_{95 \%}\right)^{\mathrm{c}}\end{array}$ & $\chi^{2}$ \\
\hline \multicolumn{11}{|c|}{ Knockdown - 2 h evaluation with $\lambda$-cyhalothrin } \\
\hline $\mathrm{Hc}-\mathrm{CA}$ & 191 & 4 & $2.39 \pm 0.42$ & $\begin{array}{c}0.001 \\
(0.0004-0.002)\end{array}$ & - & - & $\begin{array}{c}0.004 \\
(0.002-0.011)\end{array}$ & - & - & 6.76 \\
\hline Hc-GA & 221 & 4 & $1.73 \pm 0.28$ & $\begin{array}{c}0.297 \\
(0.156-0.439) \\
\end{array}$ & - & $\begin{array}{c}286.75 \\
(86.59-949.64) \\
\end{array}$ & $\begin{array}{c}1.636 \\
(0.955-6.219) \\
\end{array}$ & - & $\begin{array}{c}461.16 \\
(133.26-1595.93)\end{array}$ & 4.76 \\
\hline \multicolumn{11}{|c|}{ Knockdown $-2 h$ evaluation with $\lambda$-cyhalothrin $+P B O$} \\
\hline $\mathrm{Hc}-\mathrm{CA}$ & 278 & 4 & $2.64 \pm 0.33$ & $\begin{array}{c}0.0006 \\
(0.0005-0.0008)\end{array}$ & $\begin{array}{c}1.62 \\
(1.07-2.45)\end{array}$ & - & $\begin{array}{c}0.002 \\
(0.001-0.004)\end{array}$ & $\begin{array}{c}1.82 \\
(1.16-2.86)\end{array}$ & - & 3.87 \\
\hline Hc-GA & 182 & 5 & $1.45 \pm 0.23$ & $\begin{array}{c}0.043 \\
(0.030-0.061)\end{array}$ & $\begin{array}{c}6.94 \\
(4.40-10.93) \\
\end{array}$ & $\begin{array}{c}67.05 \\
(45.70-98.37) \\
\end{array}$ & $\begin{array}{c}0.327 \\
(0.186-0.881) \\
\end{array}$ & $\begin{array}{c}5.00 \\
(2.08-12.02) \\
\end{array}$ & $\begin{array}{c}167.81 \\
(75.53-372.82)\end{array}$ & 0.69 \\
\hline \multicolumn{11}{|c|}{ Mortality - 24 h evaluation with $\lambda$-cyhalothrin } \\
\hline $\mathrm{Hc}-\mathrm{CA}$ & 191 & 4 & $2.12 \pm 0.33$ & $\begin{array}{c}0.004 \\
(0.003-0.005)\end{array}$ & - & - & $\begin{array}{c}0.015 \\
(0.010-0.028)\end{array}$ & - & - & 1.24 \\
\hline Hc-GA & 221 & 4 & $1.71 \pm 0.32$ & $\begin{array}{c}0.816 \\
(0.631-1.167)\end{array}$ & - & $\begin{array}{c}220.03 \\
(76.89-629.65)\end{array}$ & $\begin{array}{c}4.595 \\
(2.54-15.53)\end{array}$ & - & $\begin{array}{c}308.00 \\
(79.62-1191.39)\end{array}$ & 1.54 \\
\hline \multicolumn{11}{|c|}{ Mortality - 24 h evaluation with $\lambda$-cyhalothrin $+P B O$} \\
\hline $\mathrm{Hc}-\mathrm{CA}$ & 278 & 4 & $3.30 \pm 0.42$ & $\begin{array}{c}0.0007 \\
(0.0006-0.0008)\end{array}$ & $\begin{array}{c}5.53 \\
(4.23-7.22)\end{array}$ & - & $\begin{array}{c}0.002 \\
(0.001-0.003)\end{array}$ & $\begin{array}{c}9.10 \\
(5.34-15.49)\end{array}$ & - & 4.38 \\
\hline Hc-GA & 182 & 5 & $1.57 \pm 0.24$ & $\begin{array}{c}0.047 \\
(0.034-0.067)\end{array}$ & $\begin{array}{c}17.24 \\
(11.24-26.70)\end{array}$ & $\begin{array}{c}70.55 \\
(49.49-100.57)\end{array}$ & $\begin{array}{c}0.309 \\
(0.182-0.762)\end{array}$ & $\begin{array}{c}14.84 \\
(5.19-42.39)\end{array}$ & $\begin{array}{c}188.81 \\
(91.57-389.27)\end{array}$ & 3.43 \\
\hline
\end{tabular}

$\mathrm{g}$ a.i./L of $\lambda$-cyhalothrin at technical grade producing 50 or $90 \%$ knockdown or mortality effect in the population 2 and $24 \mathrm{~h}$ after treatment, respectively.

${ }^{\mathrm{b}} \mathrm{SR}$, synergism ratio based on the relationship of $\mathrm{LD}_{50}$ or $\mathrm{LD}_{90}$ calculated from populations treated with $\lambda$-cyhalothrin and $\lambda$-cyhalothrin + PBO following the method of Robertson and Preisler [37].

${ }^{\mathrm{c}} \mathrm{RR}$, resistance ratio based on the relationships of $\mathrm{LD}_{50}$ or $\mathrm{LD}_{90}$ calculated from populations treated with $\lambda$-cyhalothrin and $\lambda$-cyhalothrin synergized with $\mathrm{PBO}$ following the method of Robertson and Preisler [37]. 


\begin{tabular}{|c|c|c|c|c|c|c|c|c|}
\hline Doses & $\begin{array}{l}\text { Population/ } \\
\text { Progeny }\end{array}$ & $\mathrm{n}$ & Knockdown (\%) & $h^{\mathrm{a}}$ & $\begin{array}{l}\text { Population/ } \\
\text { Progeny }\end{array}$ & $\mathrm{n}$ & Mortality (\%) & $h^{\mathrm{a}}$ \\
\hline \multirow{4}{*}{0.001} & Hc-CA & 24 & 33.33 & & Hc-CA & 24 & 16.67 & \\
\hline & Hc-GA & 24 & 0.00 & & Hc-GA & 24 & 0.00 & \\
\hline & $\mathrm{F}_{1} \mathrm{SR}$ & 24 & 0.00 & 1.00 & $\mathrm{~F}_{1} \mathrm{SR}$ & 24 & 0.00 & 1.00 \\
\hline & $\mathrm{F}_{1} \mathrm{RS}$ & 24 & 0.00 & 1.00 & $\mathrm{~F}_{1} \mathrm{RS}$ & 24 & 0.00 & 1.00 \\
\hline \multirow{4}{*}{0.01} & $\mathrm{Hc}-\mathrm{CA}$ & 24 & 100.00 & & $\mathrm{Hc}-\mathrm{CA}$ & 24 & 91.67 & \\
\hline & Hc-GA & 24 & 0.00 & & Hc-GA & 24 & 0.00 & \\
\hline & $\mathrm{F}_{1} \mathrm{SR}$ & 24 & 83.33 & 0.17 & $\mathrm{~F}_{1} \mathrm{SR}$ & 24 & 16.67 & 0.82 \\
\hline & $\mathrm{F}_{1} \mathrm{RS}$ & 24 & 41.67 & 0.58 & $\mathrm{~F}_{1} \mathrm{RS}$ & 24 & 0.00 & 1.00 \\
\hline \multirow{4}{*}{0.1} & $\mathrm{Hc}-\mathrm{CA}$ & 24 & 100.00 & & $\mathrm{Hc}-\mathrm{CA}$ & 24 & 100.00 & \\
\hline & Hc-GA & 24 & 33.33 & & Hc-GA & 24 & 8.33 & \\
\hline & $\mathrm{F}_{1} \mathrm{SR}$ & 24 & 100.00 & 0.00 & $\mathrm{~F}_{1} \mathrm{SR}$ & 24 & 79.17 & 0.23 \\
\hline & $\mathrm{F}_{1} \mathrm{RS}$ & 24 & 75.00 & 0.38 & $\mathrm{~F}_{1} \mathrm{RS}$ & 24 & 54.17 & 0.50 \\
\hline \multirow{4}{*}{0.5} & $\mathrm{Hc}-\mathrm{CA}$ & 24 & 100.00 & & $\mathrm{Hc}-\mathrm{CA}$ & 24 & 100.00 & \\
\hline & Hc-GA & 24 & 79.17 & & Hc-GA & 24 & 20.83 & \\
\hline & $\mathrm{F}_{1} \mathrm{SR}$ & 24 & 100.00 & 0.00 & $\mathrm{~F}_{1} \mathrm{SR}$ & 24 & 95.83 & 0.05 \\
\hline & $\mathrm{F}_{1} \mathrm{RS}$ & 24 & 95.83 & 0.20 & $\mathrm{~F}_{1} \mathrm{RS}$ & 24 & 75.00 & 0.32 \\
\hline \multirow{4}{*}{1.0} & $\mathrm{Hc}-\mathrm{CA}$ & 24 & 100.00 & & $\mathrm{Hc}-\mathrm{CA}$ & 24 & 100.00 & \\
\hline & Hc-GA & 24 & 95.83 & & Hc-GA & 24 & 33.33 & \\
\hline & $\mathrm{F}_{1} \mathrm{SR}$ & 24 & 100.00 & 0.00 & $\mathrm{~F}_{1} \mathrm{SR}$ & 24 & 100.00 & 0.00 \\
\hline & $\mathrm{F}_{1} \mathrm{RS}$ & 24 & 100.00 & 0.00 & $\mathrm{~F}_{1} \mathrm{RS}$ & 24 & 70.83 & 0.44 \\
\hline
\end{tabular}

Table 3. Dominance $(h)$ of resistance in Hippodamia convergens adults based on knockdown and mortality responses evaluated $2 \mathrm{~h}$ and $24 \mathrm{~h}$ periods after treatment with different doses ( $\mathrm{g}$ a.i. of $\lambda$-cyhalothrin) for susceptible

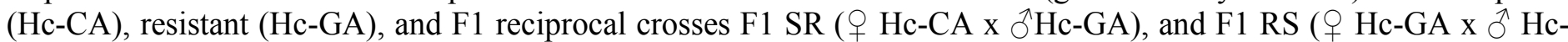
$\mathrm{CA})$. 
745

746

747

748

749

750

751

752

753

754

Table 4. Knockdown response (2h evaluation post-treatment) of resistant adults $X^{R} X^{R}$ and $\mathrm{X}^{\mathrm{R}} \mathrm{y}$ of Hippodamia convergens treated with a discriminatory dose $(0.5 \mathrm{~g}$ a.i. of $\lambda$ cyhalothrin/L). Observed and expected proportions of knockdown are presented according to the progeny genotype and the null hypothesis: parental susceptible and homozygous resistant as function of inheritance of resistance linked to the $\mathrm{X}^{\mathrm{R}}$-chromosome with 1040 tested adults.

\begin{tabular}{|c|c|c|c|c|c|c|c|}
\hline \multirow{3}{*}{$\begin{array}{l}\text { Population/ } \\
\text { Progeny }^{\mathrm{a}}\end{array}$} & \multicolumn{2}{|c|}{ Sex linkage } & & & & & \multirow{3}{*}{$\mathrm{P}$} \\
\hline & \multicolumn{2}{|c|}{ Offspring genotype } & \multirow{2}{*}{$\begin{array}{r}\begin{array}{r}\text { Expected } \\
\text { proportion }\end{array} \\
\text { Adults }^{\mathrm{b}}\end{array}$} & & \multirow{2}{*}{$\begin{array}{c}\begin{array}{c}\text { Observed } \\
\text { proportion (SE) }\end{array} \\
\text { Adults }^{\mathrm{b}}\end{array}$} & \multirow[t]{2}{*}{$\chi^{2}$} & \\
\hline & d & 오 & & $\mathrm{F} / \mathrm{n}^{\mathrm{c}}$ & & & \\
\hline \multirow[t]{4}{*}{ Hc-GA } & $\mathrm{X}^{\mathrm{R}} \mathrm{y}$ & $\mathrm{X}^{\mathrm{R}} \mathrm{X}^{\mathrm{R}}$ & 0.00 & $\mathrm{~A} / 20$ & $0.67(0.05)$ & $\mathrm{NC}^{\mathrm{d}}$ & $\mathrm{NC}$ \\
\hline & & & 0.00 & $\mathrm{~B} / 30$ & $0.37(0.03)$ & $\mathrm{NC}$ & $\mathrm{NC}$ \\
\hline & & & 0.00 & $\mathrm{C} / 30$ & $0.15(0.06)$ & $\mathrm{NC}$ & $\mathrm{NC}$ \\
\hline & & & 0.00 & $\mathrm{D} / 40$ & $0.48(0.12)$ & $\mathrm{NC}$ & $\mathrm{NC}$ \\
\hline Hc-CA & $X^{S} y$ & $\mathrm{X}^{\mathrm{S}} \mathrm{X}^{\mathrm{S}}$ & 1.00 & $(\mathrm{~A}-\mathrm{E}) / 150$ & $1.00(0.00)$ & 0.00 & 1.00 \\
\hline \multirow[t]{4}{*}{ F1 RS } & $\mathrm{X}^{\mathrm{R}} \mathrm{y}$ & $\mathrm{X}^{\mathrm{R}} \overline{\mathrm{X}}^{\mathrm{s}}$ & 0.50 & $\mathrm{~A} / 30$ & $0.75(0.00)$ & 7.50 & $0.01^{*}$ \\
\hline & & & 0.50 & $\mathrm{~B} / 30$ & $0.65(0.06)$ & 2.70 & 0.10 \\
\hline & & & 0.50 & $\mathrm{C} / 30$ & $0.77(0.07)$ & 8.53 & $<0.00 *$ \\
\hline & & & 0.50 & $\mathrm{D} / 30$ & $0.80(0.01)$ & 11.5 & $<0.00 *$ \\
\hline F1 SR & $\mathrm{X}^{\mathrm{S}} \mathrm{y}$ & $\mathrm{X}^{\mathrm{R}} \mathrm{X}^{\mathrm{S}}$ & 1.00 & $(\mathrm{~A}-\mathrm{E}) / 150$ & $1.00(0.00)$ & 0.00 & 1.00 \\
\hline \multirow[t]{4}{*}{$\mathrm{BC} 1$} & $\mathrm{X}^{\mathrm{R}} \mathrm{y}$ & $\mathrm{X}^{\mathrm{R}} \mathrm{X}^{\mathrm{R}}$ & 0.00 & $\mathrm{~A} / 30$ & $0.00(0.00)$ & $\mathrm{NC}^{4}$ & $\mathrm{NC}$ \\
\hline & & & 0.00 & $\mathrm{~B} / 30$ & $0.18(0.08)$ & $\mathrm{NC}$ & $\mathrm{NC}$ \\
\hline & & & 0.00 & $\mathrm{C} / 30$ & $0.05(0.03)$ & $\mathrm{NC}$ & $\mathrm{NC}$ \\
\hline & & & 0.00 & $\mathrm{D} / 30$ & $0.53(0.02)$ & $\mathrm{NC}$ & $\mathrm{NC}$ \\
\hline \multirow[t]{5}{*}{$\mathrm{BC} 2$} & $\mathrm{X}^{\mathrm{R}} \mathrm{y}$ & $\mathrm{X}^{\mathrm{R}} \mathrm{X}^{\mathrm{S}^{-}}$ & 0.50 & $\mathrm{~A} / 30$ & $0.63(0.06)$ & 1.88 & 0.16 \\
\hline & & & 0.50 & $\mathrm{~B} / 30$ & $0.64(0.02)$ & 2.41 & 0.12 \\
\hline & & & 0.50 & $\mathrm{C} / 30$ & $0.63(0.06)$ & 1.88 & 0.16 \\
\hline & & & 0.50 & $\mathrm{D} / 30$ & $0.71(0.12)$ & 5.21 & $0.02 *$ \\
\hline & & & 0.50 & $\mathrm{E} / 30$ & $0.86(0.04)$ & 15.2 & $<0.00^{*}$ \\
\hline $\mathrm{BC} 3$ & $\mathrm{X}^{\mathrm{S}} \mathrm{y}$ & $X^{\mathrm{R}} \mathrm{X}^{\mathrm{S}}$ & 1.00 & $(A-D) / 110$ & $1.00(0.00)$ & 0.00 & 1.00 \\
\hline $\mathrm{BC} 4$ & $\mathrm{X}^{\mathrm{S}}$ & $\mathrm{X}^{\mathrm{S}} \mathrm{X}^{\mathrm{S}}$ & 1.00 & $(\mathrm{~A}-\mathrm{E}) / 150$ & $1.00(0.00)$ & 0.00 & 1.00 \\
\hline
\end{tabular}

${ }^{\mathrm{a}}$ Susceptible (Hc-CA) and resistant (Hc-GA) populations; F1 RS, cross of 9 + Hc-GA x ${ }^{\hat{\lambda}} \mathrm{Hc}-$ $\mathrm{CA}$, and F1 SR cross of $q \mathrm{Hc}-\mathrm{CA} \times{ }^{\lambda} \mathrm{Hc}-\mathrm{GA}$. The backcrosses $\mathrm{BC} 1$ ( $+\mathrm{Hc}-\mathrm{GA} \times{ }^{\lambda} \mathrm{F} 1 \mathrm{RS}$ ),

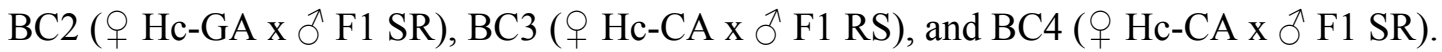

${ }^{\mathrm{b}}$ Proportion of adults (mean pooled for males and females).

${ }^{\mathrm{c}} \mathrm{F}$ stands for families, and $\mathrm{n}$ stands for number of insects tested per family for each population, progeny, and backcrosses.

${ }^{\mathrm{d}} \mathrm{NC}$ stands for qui-square and $\mathrm{p}$-values not determined; while *stands for significant deviation from the null hypotheses. 
Table 5. Mortality response $24 \mathrm{~h}$ post-treatment of resistant adults $X^{R} X^{R}$ and $X^{R} y$ of Hippodamia convergens treated with a discriminatory dose $(0.5 \mathrm{~g}$ a.i. of $\lambda$-cyhalothrin $/ \mathrm{L})$. Observed and expected proportions of mortality are presented according to the progeny genotype considering the null hypothesis: parental susceptible and homozygote resistant as function of inheritance of resistance linked to the $\mathrm{X}^{\mathrm{R}}$-chromosome with 1040 tested adults.

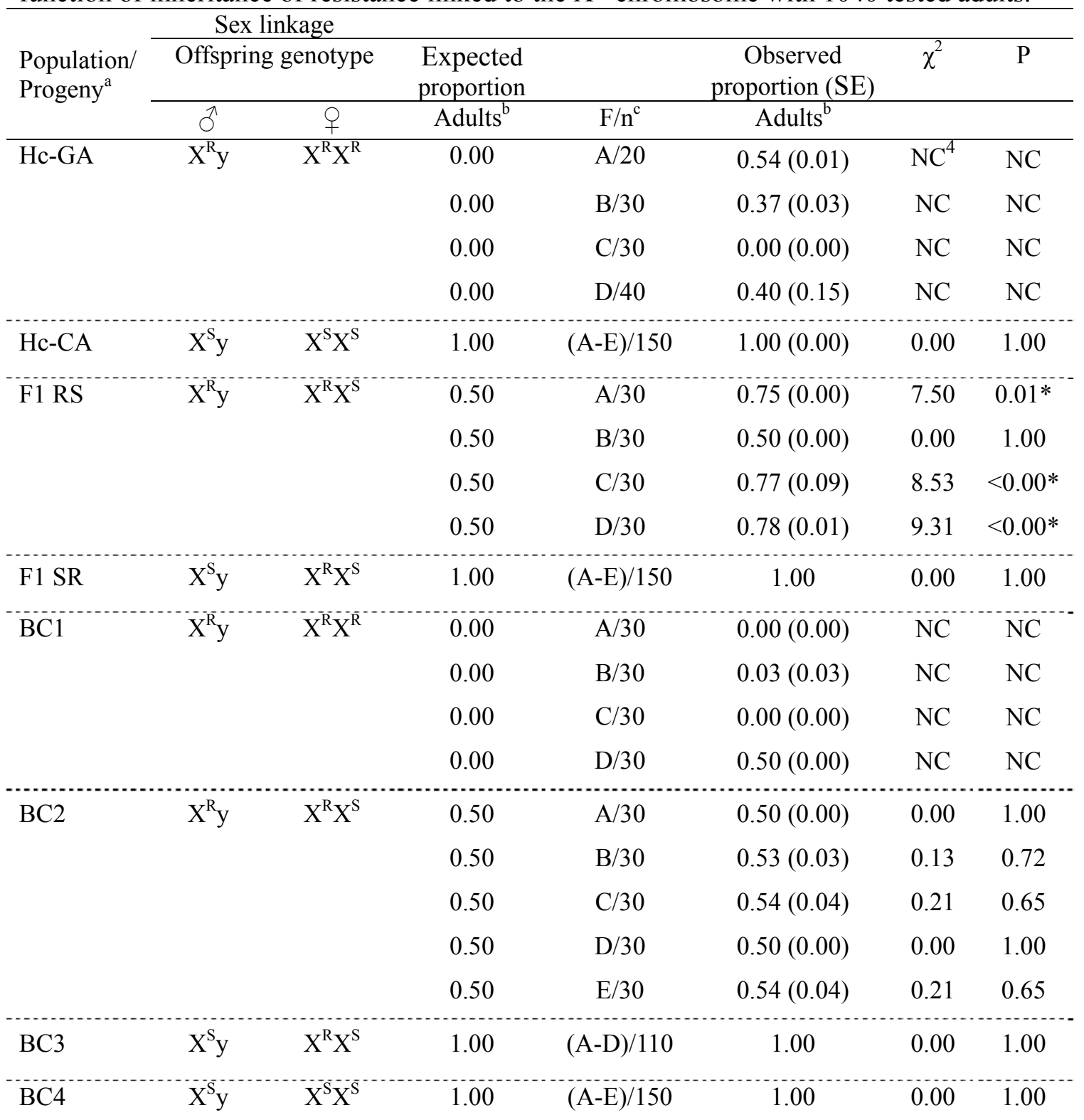

${ }^{a}$ Susceptible (Hc-CA) and resistant (Hc-GA) populations; F1 RS, cross of $+\mathrm{Hc}-\mathrm{GA} \times{ }^{\lambda} \mathrm{Hc}-\mathrm{CA}$, and

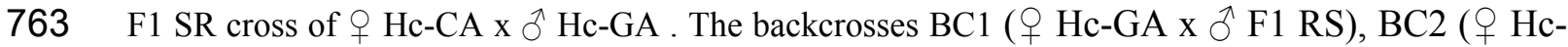

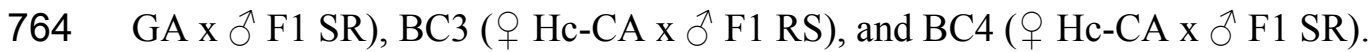

$765{ }^{\mathrm{b}}$ Proportion of adults (pooled for males and females).

$766{ }^{\mathrm{c}} \mathrm{F}$ stands for families, and $\mathrm{n}$ stands for number of insects tested per family for each 767 population, progeny, and backcrosses.

$768{ }^{\mathrm{d}} \mathrm{NC}$ stands for qui-square and p-values not determined; while *stands for significant 769 deviation from the null hypotheses. 